\title{
Numerical Prediction and Corresponding Circular Economy Approaches for Resource Optimisation and Recovery of Underground Structures
}

\author{
Han-Mei Chen ${ }^{1,4}$ (D) Rongxin Zhou $^{2} \cdot$ Cristian Ulianov $^{3}$
}

Received: 2 July 2019/Revised: 4 December 2019/Accepted: 20 December 2019/Published online: 10 February 2020

(C) The Author(s) 2020

\begin{abstract}
The transition from a linear economy to a circular economy is a significant component of economic, environmental and social sustainability. Underground metro infrastructures such as tunnels can play a vital role in a circular economy, resulting in greater sustainability and less contribution to climate change. This paper presents numerical models of small-scale brick-lined railway tunnels to identify the critical locations, and then proposes corresponding circular approaches and solutions for the
\end{abstract}

This paper presents predicted results of segmental linings of underground structures such as metros and tunnels by numerical modelling to easily identify the potentially weaker areas for repair locally rather than globally. In this way, the repair and demolition waste can be largely utilised either for reuse or recycling, depending on their mechanical properties.

Han-Mei Chen

han-mei.chen@manchester.ac.uk;

Hanmei.Chen@liverpool.ac.uk

Rongxin Zhou

r.zhou2@lboro.ac.uk

Cristian Ulianov

cristian.ulianov@ncl.ac.uk

1 Department of Mechanical, Aerospace and Civil Engineering, School of Engineering, University of Manchester, Oxford Rd., Manchester M13 9PL, UK

2 Wolfson School of Mechanical, Electrical and Manufacturing Engineering, Loughborough University, Loughborough LE11 3TU, UK

3 NewRail Centre for Railway Research, Newcastle University, Stephenson Building, Newcastle NE1 7RU, UK

4 School of Architecture, University of Liverpool, Liverpool L69 7ZN, UK

Communicated by Marin Marinov. design, maintenance, life extension and end-of-service-life (EoSL) stages of underground infrastructures. The proposed numerical model is firstly verified with respect to the relevant experimental model based on tests under various loading conditions. The results demonstrate that detailed failure processes can be realistically captured by the numerical model, while the macroscopic behaviour compares well with experimental observations. Numerical modelling and subsequent prediction stand out as a practical approach and a powerful performance-based tool for analysing the reuse/recycling potential of metro tunnels and then carrying out easy repair and design for adaptability, disassembly and recoverability of underground infrastructures for a circular economy.

Keywords Resource optimisation · Waste recovery · Underground metro infrastructures · Numerical modelling · Circular economy

\section{Introduction}

A circular economy aims to increase resource efficiency and retain resources within the economy, compared with a linear economy where the resources are downcycled or disposed of in landfills [1]. In recent years, there has been a growing interest in developing a circular economy in construction for policymakers, industry, academia, real estate investors and the public. Policies, targets and guidance for a circular economy, resource efficiency and waste management, sustainability action plans, and resource and waste roadmaps [2-11] have been established to reduce the environmental impacts of construction and demolition waste. In the construction industry, the construction and maintenance of aboveground and underground 
infrastructures, e.g. buildings, roads, metro and railway tunnels, and other infrastructure assets, represent the largest resource footprint, with $42.4 \mathrm{Gt}$ consumed annually, equivalent to almost $50 \%$ of global material consumption and $20 \%$ ( $>9 \mathrm{Gt}$ of $\mathrm{CO}_{2}$ eq.) of global greenhouse gas (GHG) emissions [12]. By 2050, the urban construction stock in Europe is expected to grow by around $12 \mathrm{Gt}$ (13\%) compared with 2015 [13], to satisfy the needs of the future urban population. Thus, a report by the United Nations [14] pointed out that the construction sector is the key to achieving the climate change mitigation goals set in the Paris Agreement. Construction materials in many parts of the world are also increasingly scarce. Accordingly, urgent action is needed to substantially improve the resource efficiency of urban development, in line with the Sustainable Development Goal 11 [15].

In the construction sector, the currently wasteful longestablished practices of the predominant "take-make-usedispose" linear economy model need to be rethought, and a shift to a circular economy (CE) is needed, with innovation to tackle climate change and resource scarcity in order to achieve value retention and to create new opportunities $[1,16,17]$. A circular economy is based on reusing biological and technological resources for as long as possible in closed-loop systems [18]. In a future circular economy, all aboveground and underground infrastructures (structures/components/materials) would be material and product banks and demountable/adaptable to retain high-value components and materials, and remanufacture of components from EoSL structures would be carried out and stored locally and then reused in new structures, also locally, to minimise transport cost [19]. Reclamation and reuse could contribute to the UK demand for around $400 \mathrm{Mt}$ of new materials each year for new construction, replacement or maintenance of infrastructure and buildings [19].

\subsection{Underground Construction}

In the underground construction industry in Europe, tunnel projects form a large portion of the infrastructure market, and there is continuous demand for new tunnels. Road, metro and railway tunnels play a central role in the modern economy, with thousands of people and tonnes of goods passing through them every day. Failure of such critical links may lead to significant disruption of large parts of the European transportation system [20]. As the key building material of the majority of modern underground infrastructures, the unrivalled attributes of concrete have helped boost global cement production since the 1950s [21]. In 2016, world cement production generated around 2.2 billion tonnes of $\mathrm{CO}_{2}$-equivalent to $8 \%$ of the global total [21]. From an economic perspective, the increasing volatility of raw material prices has been highlighted as one of the main reasons for applying CE principles [22]. As an example, the price of cement and construction metals in the UK increased $9.4 \%$ and $7.2 \%$, respectively, from 2014 to 2018 [23]. The old railway tunnels built in the nineteenth and twentieth centuries are supported by a masonry structure made of clay bricks or stone blocks [24]. Klang et al. [25] proved through a case study that the environmental impact of a brick reuse process is only a very small fraction of the potential impact of primary production. The embodied carbon savings of reclaiming 1 tonne of bricks is up to 0.9 tonnes compared with recycling and landfilling [26].

(i) For aboveground infrastructures such as buildings, several studies have begun to explore ways to embody emission reduction and promote $\mathrm{CE}$ approaches in other stages of the life cycle, such as design [27-29] or end of life [19, 30]. For instance, the reuse of concrete panels reduced the cost of new construction by $20-30 \%$, in addition to having a very low carbon dioxide $\left(\mathrm{CO}_{2}\right)$ footprint [27, 31, 32]. Studies on demolishing end-ofservice-life (EoSL) buildings for recoverability and designing new buildings for optimisation have been widely highlighted. Steel reuse and recycling in buildings, e.g. steel sheet cladding, light steel as door frames, load-bearing steel sections, has been investigated by researchers [33-37] without reducing large quantities of construction and demolition waste. The reuse and recovery of clay bricks and other masonry blocks jointed by either lime-based or cement-based mortar has also been increasingly addressed to retain the high embodied energy of these products $[10,19,38]$. In terms of concrete and its related composite structures, research on demountable composite beams has been conducted as design for disassembly (DfD) during demolition $[39,40]$, and the reuse and recycling potential of precast concrete wall panels and concrete slabs from the demolition of high-rise buildings has been discussed by Huuhka et al. [27] and the Kerkrade project [41].

(ii) A few studies have already investigated the circular economy in the underground infrastructures. The EU-funded project DRAGON [42] has developed a system to automatically analyse and sort around 800 million tonnes of materials from the soil and rock excavated during the boring of tunnels and other underground infrastructures in the near future. However, circular economy principles have not been thoroughly investigated for being implanted in underground infrastructures such as metro and railway tunnels, which are unique 
structures suffering from various surrounding soils/ rocks with massive soil-structure interactions and underground water, therefore subjected to massive surrounding loadings (pressures). Thus, their key design considerations and structural behaviour are different from other structures such as buildings and bridges, as the main bearing element in underground tunnels is the surrounding soils and rocks [20]. Therefore, it needs very special design, robust connection to the linings, and corresponding numerical simulations to understand the underground structural behaviours before the promotion of proper CE approaches. The geological uncertainties related to tunnelling are a challenge [20]. In addition, although various numerical models have been developed for the performance of structures such as bridges and buildings [43-47], few studies have focused on underground infrastructures surrounded by soil pressure [48], and even fewer have been validated experimentally [49].

\subsection{Aims and Outline}

This research aims to introduce a sound numerical model to predict the structural performance of an underground structure and then to propose appropriate CE approaches particularly for underground infrastructures. The remainder of the paper is organised as follows. Section 2 outlines the key challenges in achieving increased resource efficiency in underground infrastructures for a circular economy, and introduces potential circular economy approaches and solutions. Section 3 describes the numerical simulation and prediction of the lining structures validated by experimental models. Section 4 draws conclusions regarding the feasibility of the numerical prediction and potential future research based on the paper. It should be noted that the numerical models and methodology can be adapted to both segmental clay brick and concrete lining, although this paper focuses on railway and metro tunnels with brick linings in European countries. In addition, it can serve as a benchmark for worldwide urban underground infrastructures.

\section{Perceived Challenges and Potential Circular Economy Solutions for Underground Infrastructures}

The supports (linings) of underground infrastructures are traditionally made of stone blocks and brick masonry to endure over hundreds of years. For example, the oldest French tunnels on the record exceed 190 years [50]. After the twentieth century, modern linings are normally made of reinforced concrete and are designed to serve for at least 150 years [51-53].

There are some perceived challenges in this field as shown below:

(1) During the service life, maintenance of underground infrastructures is not easy, especially for concrete linings. Precast segmental linings are designed for easy construction but not for easy repair as the segments have been assembled piece by piece in a sequence and jointed by segment accessories, e.g. plastic dowels in circumferential joints and bolts in radial (or longitudinal) joints [54]. Once there is a need to replace a few segments in some areas, the whole system has to be taken over, which is not ideal.

(2) The real service life (age) of an underground structure may be much shorter than expected, which means the resource is not efficiently used. This may be due to significant defects or degradation over time at a local area, a decommissioning plan or the need to enlarge the structure, e.g. modernisation of Victorian railway tunnels for the twenty-first century [51]. The George Massey tunnel was only 60 years old at the time of decommissioning [55]. Urgent action is needed to improve resource efficiency, in line with Sustainable Development Goal 11 [15].

(3) The EoSL typically renders lining components unusable, as they are not designed for adaptability, disassembly and recoverability. The enlargement of existing tunnels results in resource loss of the existing lining elements. For instance, old bricklined railway tunnels are refilled with foam concrete and excavated to a larger tunnel profile. Thus, bricks are crushed into pieces for recycling or landfilling $[51,56]$. Unlike segmental concrete linings that have the potential to be demounted and reused, sprayed concrete lining can only be recycled if needed, with no upcycling ability. Similarly, for decommissioned railway tunnels, it is normally suggested that a tunnel lining be abandoned, leaving the high embodied energy products unused [51]. Even after the designed service life, brick-lined railway tunnels can be upgraded at weaker areas and still function for another hundred years or more.

Table 1 summarises some of the circular approaches and solutions which can be used for underground infrastructures. The cultural transition from a linear to a circular economy requires a step change, from traditional design to design for a circular economy, especially for longevity (easy repair), adaptability, disassembly and flexibility (DfL/DfA/DfD/DfF). 
Table 1 Summary of circular approaches and solutions for underground infrastructures

\begin{tabular}{|c|c|}
\hline Challenges & Potential circular approaches and solutions \\
\hline \multicolumn{2}{|l|}{ Existing brick lining } \\
\hline Repair of damaged historical bricks & $\begin{array}{l}\text { Numerical simulations of lining behaviour and numerical prediction of weaker } \\
\text { areas and change of stronger bricks at worn areas }\end{array}$ \\
\hline \multirow[t]{2}{*}{$\begin{array}{l}\text { Recovery (reuse) of non-damaged historical bricks in the } \\
\text { enlargement of existing railway tunnels }\end{array}$} & $\begin{array}{l}\text { Technical feasibility of reclamation of bricks during local excavation to embrace } \\
\text { the reuse of existing construction products, from laboratory-scale development to } \\
\text { numerical simulations }\end{array}$ \\
\hline & $\begin{array}{l}\text { Development of a tunnel boring machine (TBM) to achieve reclamation and further } \\
\text { excavation procedures, with embedded punching and saw cutting to reclaim } \\
\text { bricks from mortar joints [19] }\end{array}$ \\
\hline $\begin{array}{l}\text { Updating product value to promote the economics of } \\
\text { brick reclamation }\end{array}$ & $\begin{array}{l}\text { Remanufacturing the reclaimed brick into brick slips with higher economic value as } \\
\text { a façade for new railway stations and new metros [19] }\end{array}$ \\
\hline \multicolumn{2}{|l|}{ New segmental concrete lining } \\
\hline $\begin{array}{l}\text { Designing for easy repair, disassembly and } \\
\text { recoverability (waste reuse) }\end{array}$ & $\begin{array}{l}\text { Developing new designs for the circumferential and radial joints of concrete } \\
\text { segments to enable easy repair and demountability, from laboratory-scale } \\
\text { development to numerical simulations (placement of stronger bricks at weaker } \\
\text { areas) }\end{array}$ \\
\hline Designing for adaptability & $\begin{array}{l}\text { Developing new forms of segments which can be easily adapted and used from a } \\
\text { smaller lining diameter to larger lining diameter, and vice versa, with various key } \\
\text { stones }\end{array}$ \\
\hline \multicolumn{2}{|l|}{ New sprayed concrete lining } \\
\hline $\begin{array}{l}\text { Designing for disassembly and recoverability (waste } \\
\text { reuse) }\end{array}$ & $\begin{array}{l}\text { Developing new methods for spraying of concrete which is demountable when } \\
\text { needed }\end{array}$ \\
\hline
\end{tabular}

The CE approach includes reversible design for new material, maintenance and life extension of existing material for resource optimisation, and deconstruction/demolition of EoSL material for resource recovery.

\section{Prediction by Numerical Simulation}

This paper introduces a sound numerical model to predict the structural performance of underground infrastructures during their service life (stage 1 in Fig. 1). It presents how numerical prediction verified by experimental models could guide further $\mathrm{CE}$ approaches:

(1) Identifying the critical locations where stresses are close to the failure strength

- New railway tunnels at the design stage, to strengthen the weaker sections by using stronger components to increase reusability

- Existing railway tunnels at the maintenance/life extension stage, to repair/replace the weaker components (materials) for recycling with stronger and/or better designed components to increase reusability
In numerical modelling, when the stress approaches the failure strength of bricks, the components in the critical locations yield, and ultimately fail and are crush under compression. At the design stage, stronger and reusable components with higher embodied energy/more resources need only be used in these weaker areas, while normal components can be elsewhere, to optimise the resource utilisation and efficiency of the underground infrastructure. At the maintenance/life extension stage, the components in dangerous sections of underground tunnels yield and fail when reaching the failure strength, crushing into pieces that can be collected for recycling. Then, stronger reusable components with higher embodied energy/more resources can be implemented in these weaker areas. For instance, existing masonry in railway tunnels can be refurbished or retrofitted by repairing the weaker components rather than decommissioning them.

(2) Assessing the quality of all components by region This may be applied to existing railway tunnels at the EoSL stage, to optimise the components for reuse over materials for recycling and disposal. The components in non-critical locations do not yield, preserving their linear-elastic or non-linear-elastic status and remaining intact. Thus, all the lining components in the good condition can be reclaimed for reuse rather than recycled to retain their value. 


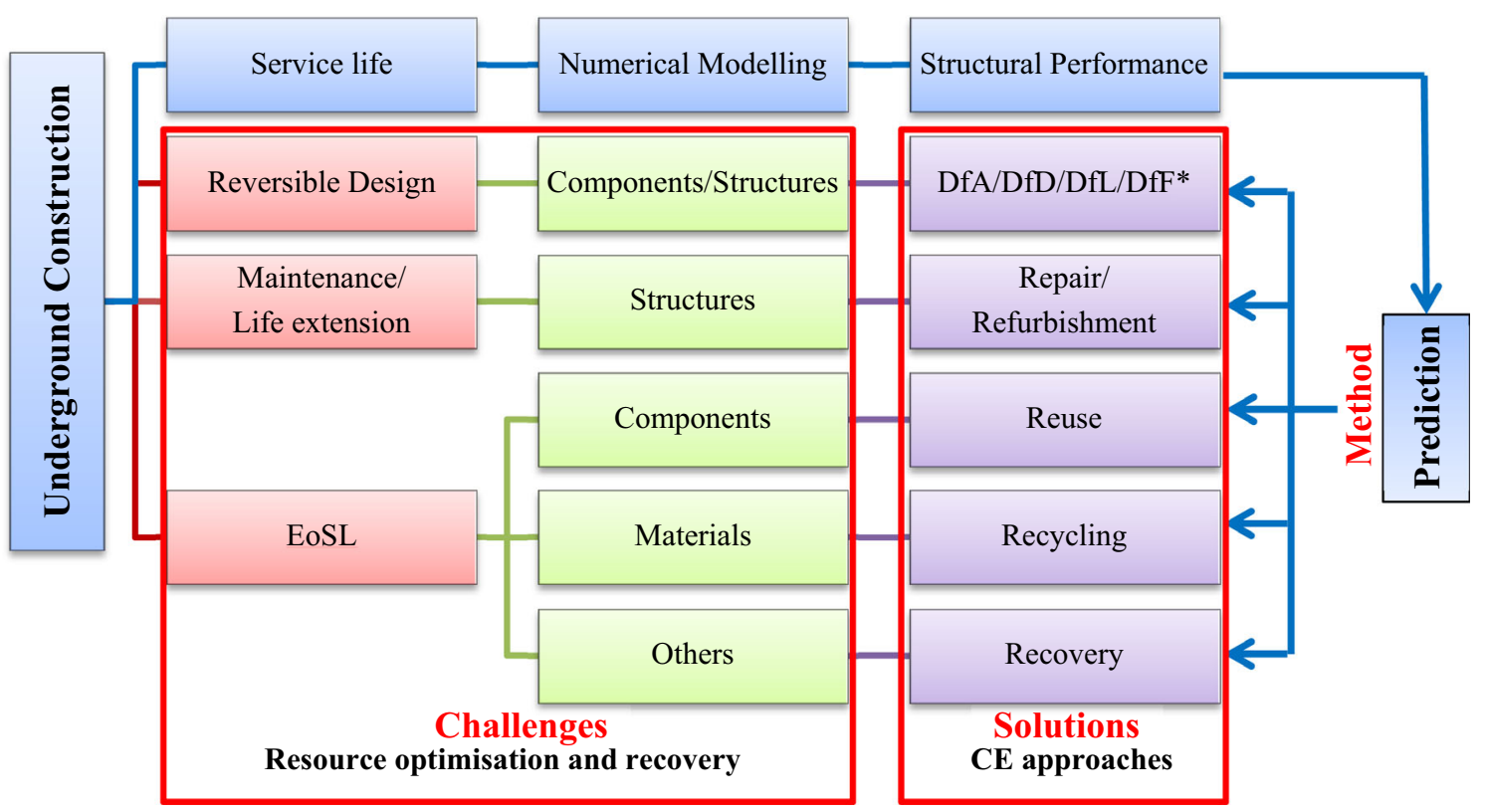

*: DfA-Design for adaptability; DfD-Design for disassembly; DfL-Design for longevity; DfF-Design for flexibility

Fig. 1 Methodology for CE solutions in underground infrastructures

The components in dangerous sections are more likely to endure heavy pressure and yield. For safety reasons, the remaining unreliable ones that are close to the yield strength can be recycled to optimise the resource recovery of the underground infrastructures.

Table 2 summarises the required predictions relating to critical locations and quality of materials at various stages of underground infrastructure service life, along with the expected results in numerical simulation and the implications of these results.

Numerical models were developed by using UDEC Universal Distinct Element Code (UDEC) software, which is based on the distinct element method. The numerical results were then compared with the experimental values. UDEC modelling can simulate local behaviours well, and thus it can support precise prediction of weaker areas. A simplified micro-modelling strategy, as described by Idris et al. [48], was employed in UDEC. In this strategy, the thickness of mortar joints is assumed to be zero, and thus there are only brickwork blocks joined by zero-thickness interfaces. In the simulations, the Mohr-Coulomb constitutive model was used for soil and brick masonry structures similar to brittle materials such as rocks. Most of the material properties were derived from laboratory property testing. Both deep-seated and shallow underground infrastructures were simulated using the numerical modelling, varying the depth of overburden soil and the load conditions from uniform to concentrated load.

\subsection{Model Generation}

For this study, three small-scale brick-lined tunnel models were built both numerically and in the laboratory, and were subjected to static load until failure occurred, so as to mimic the tunnel instability issue and to assess the mechanical behaviour progression during the loading. Advanced non-destructive monitoring techniques including laser scanning and photogrammetry, rather than extensometers, were used in the experiment during the loading to record the lining deformation and defects [57-59]. The numerical and experimental models were of the same geometrical dimensions, as shown in Fig. 2. The rigid box filled with surrounding sand is $2017.5 \mathrm{~mm}$ long, $332 \mathrm{~mm}$ wide and $1500 \mathrm{~mm}$ tall. $H$ is the surrounding soil depth from the overburden soil surface to the bottom of the box, $h$ is the surrounding soil depth from the overburden soil surface to the tunnel crown, and $P$ is the load applied over the load spreader beam and plate to the homogeneous soil and the tunnel. There were three brick courses at the tunnel arch, as in a traditional brick-lined tunnel built in the Victorian era in the UK. The sidewalls were in a stretcher bond, as can be seen in the right image in Fig. 2 .

Table 3 presents variations of the three model tests at $1075 \mathrm{~mm}$ and $1170 \mathrm{~mm}$ soil depth under uniform and concentrated load, respectively.

For the boundary condition, the left and right sides and the bottom side were assigned as rollers (shown in Fig. 3). First, the model was set to equilibrium state to simulate the 
Table 2 Summary of numerical predictions to guide circular approaches for underground infrastructures

\begin{tabular}{llll}
\hline $\begin{array}{l}\text { Required } \\
\text { Prediction }\end{array}$ & $\begin{array}{l}\text { Stage of underground } \\
\text { infrastructure }\end{array}$ & Expected results & Implications \\
\hline $\begin{array}{c}\text { Critical } \\
\text { locations }\end{array}$ & $\begin{array}{l}\text { Design } \\
\text { Maintenance or life } \\
\text { extension }\end{array}$ & $\begin{array}{l}\text { Showing yield and failed area } \\
\text { Showing yield and failed area }\end{array}$ & $\begin{array}{l}\text { Use stronger components } \\
\text { Recycling old components; use stronger } \\
\text { components }\end{array}$ \\
& EoSL & $\begin{array}{c}\text { Showing non-yielded area (i.e. linear/non-linear- } \\
\text { elastic status) }\end{array}$ & $\begin{array}{c}\text { Reuse old components } \\
\text { Showing yield and failed area }\end{array}$ \\
\hline
\end{tabular}

Fig. 2 The brick-lined railway tunnel under uniform load (adapted from [49])

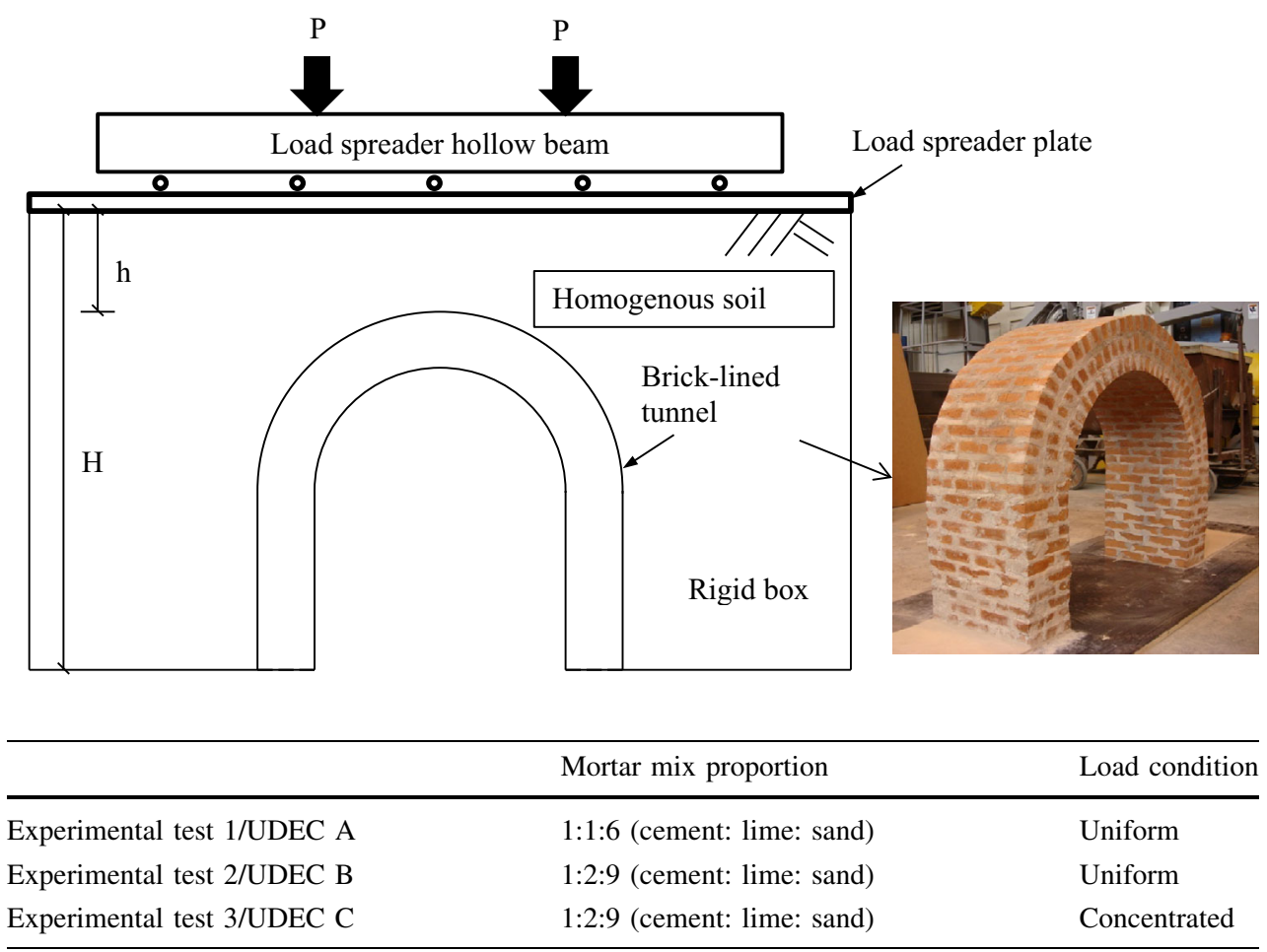

Table 3 Variations for experimental and numerical tests

\subsection{Experimental Validation}

The experimental models were subjected to uniform and concentrated load, as detailed by Chen et al. [49]. A comparison of the results is shown in Fig. 4. The numerical modelling results are consistent with the experimental results, with a similar displacement tendency. Therefore, the developed numerical models were quantitatively validated by experimental tests.

\subsubsection{Under Distributed Load}

\section{Deflection behaviour}

Considering the UDEC A simulating the experimental test 1 under uniform load, the deformation trend in the numerical simulation illustrates that the lining deforms and 
Fig. 3 UDEC model grids with boundary conditions

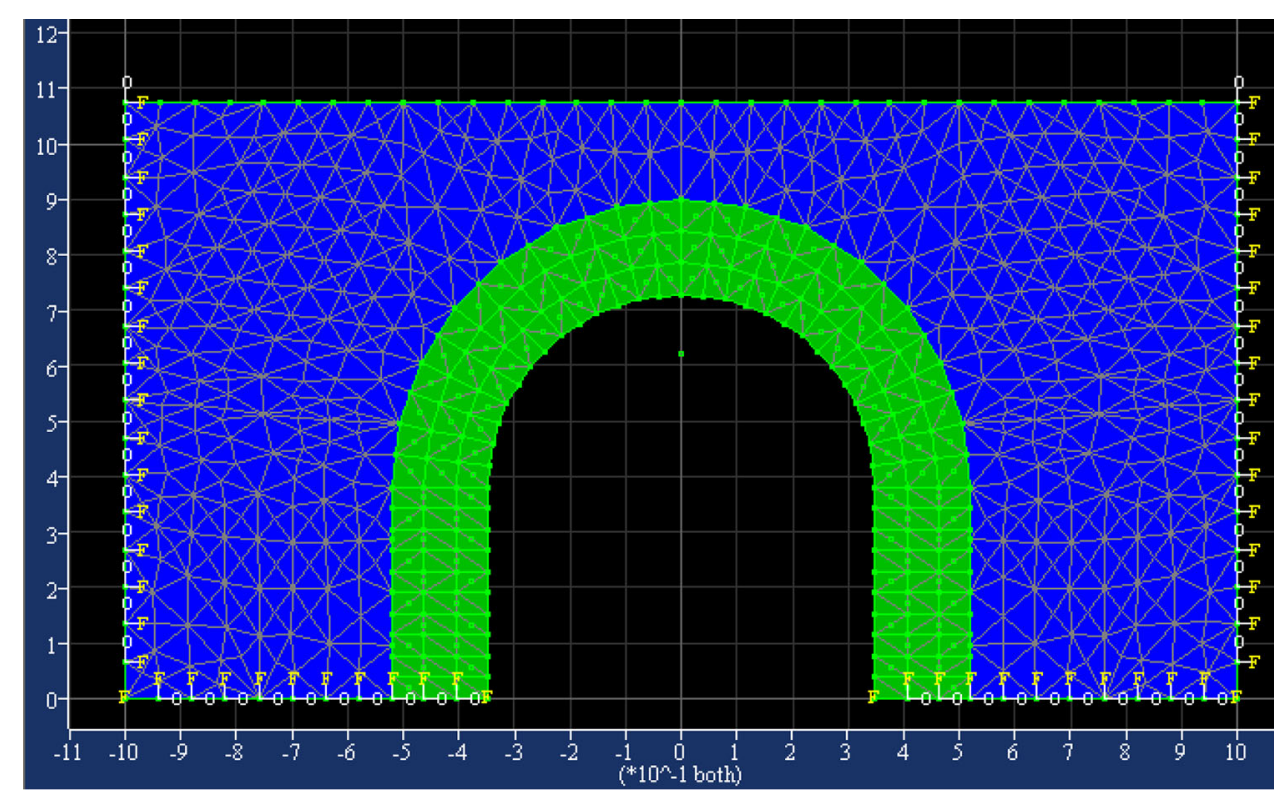

Table 4 The optimum mechanical properties of brickworks

\begin{tabular}{lllllll}
\hline Mortar mix & $E(\mathrm{MPa})$ & $v$ & $c(\mathrm{MPa})$ & $\Phi\left(^{\circ}\right)$ & $\mathrm{JKn}=\mathrm{JKs}(\mathrm{GPa} / \mathrm{m})$ & $J \varphi\left(^{\circ}\right)$ \\
\hline $1: 1: 6$ & 384.33 & 0.2 & 0.16 & 50 & 112.97 & 25 \\
$1: 2: 9$ & 218.67 & 0.2 & 0.1 & 52 & 64.28 & 25 \\
\hline
\end{tabular}

Table 5 Surrounding soil, brickwork/soil joint and brickwork block joint properties

\begin{tabular}{|c|c|c|c|c|c|}
\hline & $\rho\left(\mathrm{kg} / \mathrm{m}^{3}\right)$ & & & $v$ & $\varphi$ \\
\hline \multirow[t]{2}{*}{ Surrounding soil } & 1832 & 26 & & $0.3^{\mathrm{a}}$ & $44^{\circ}$ \\
\hline & $\mathrm{JKn}(\mathrm{GPa} / \mathrm{m})$ & $\mathrm{JKs}(\mathrm{GPa} / \mathrm{m})$ & $J \varphi$ & $J \mathrm{c}$ & $\mathrm{JTr}(\mathrm{MPa})$ \\
\hline Brickwork/soil joint & 112.97 & 112.97 & $25^{\mathrm{a}}$ & 0 & 0 \\
\hline Brickwork blockjoint & & & & 0.1521 & 0.218 \\
\hline
\end{tabular}

aYoung's modulus and Poisson's ratio of the surrounding soil refer to Juspi [60]. The friction angle of the joint $(J \varphi)$ refers to Idris et al. [48]
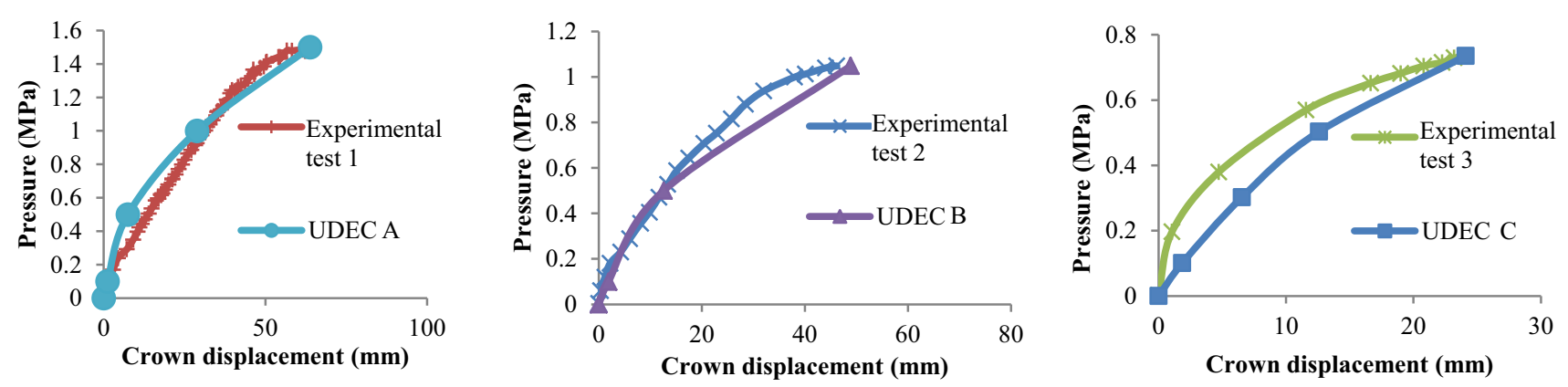

Fig. 4 Experimental tests versus numerical models (pressure versus displacement) 
Fig. 5 Displacement vectors for UDEC A under uniform load $(H=1075 \mathrm{~mm})$

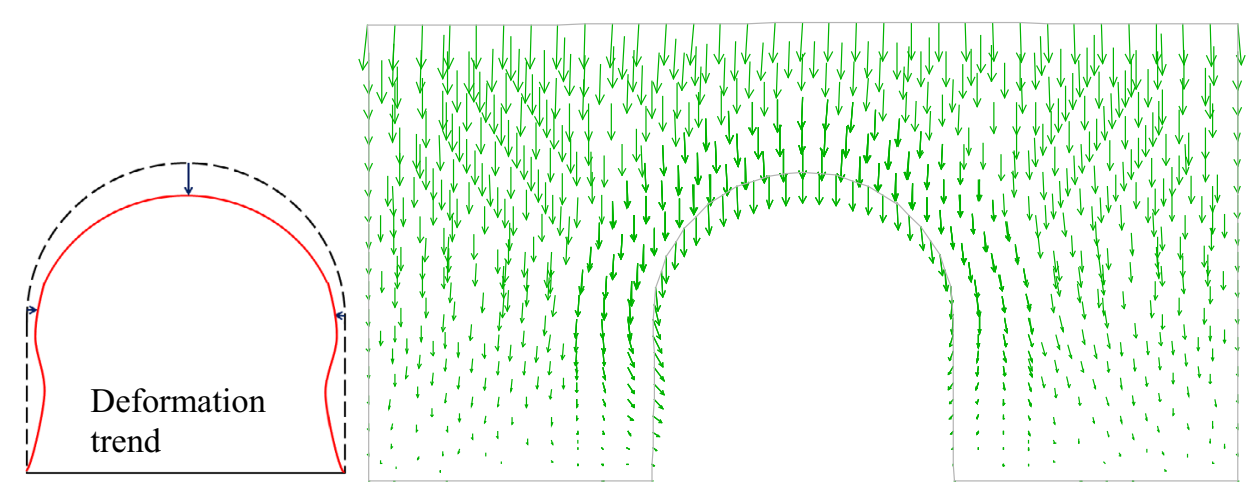

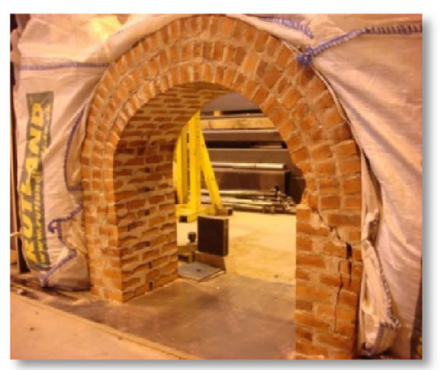

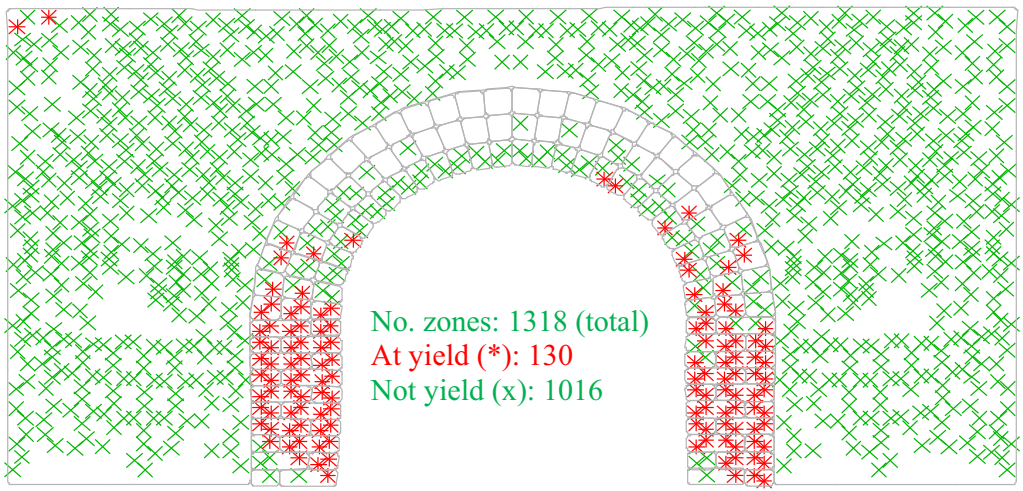

Fig. 6 Failure state of UDEC A compared with experimental test 1 under uniform load $(H=1075 \mathrm{~mm})$

is squeezed inwards, especially at the crown, and bent everywhere (see Fig. 5). It was in line with the experimental results leading to a crushing phenomenon just at the end of the arch, i.e. the springing. The same pattern was found in the results of UDEC B simulating the experimental test 2 .

\section{Mode of failure and cracking behaviour}

Because of its unique shape, the tunnel acts as a monolith on the arch of the tunnel under a uniformly distributed load to transmit the load downwards to the two sidewalls. Both UDEC A and B yielded and failed in shear under uniform load at the sidewalls (see Figs. 6 and 7). During the loading process, the accompanying cracks started from the end of the arch and spread diagonally towards the bottom of the sidewalls, ultimately leading to imminent shear failure. It was again in line with the experimental results, as shown in Fig. 6 with visible diagonal cracks.

Thus, after both quantitative (crown displacement versus pressure) and qualitative (deflection behaviour and mode of failure) validation by experimental model tests, the developed numerical models can be effectively used to predict the weaker areas of a railway masonry tunnel and its stability. This encouraged further prediction of weaker areas in UDEC $\mathrm{C}$ under concentrated load, which will be discussed in Sect. 3.2.2.

\subsubsection{Under Concentrated Load}

To mimic the real situation of the brick-lined structure with the overburden soil under a concentrated load $330 \mathrm{~mm}$ wide, various soil depths $(\mathrm{H})$ from $980 \mathrm{~mm}$ to $1265 \mathrm{~mm}$ were generated in the numerical prediction. The following results show an overburden soil depth of $1170 \mathrm{~mm}$.

\section{Deflection behaviour}

Considering UDEC $\mathrm{C}$ under concentrated load, the deformation trend in Fig. 8 shows that the lining deformed inwards at the crown and conversely deformed outwards at the sidewalls. It was again in line with the experimental results.

\section{Mode of failure and cracking behaviour}

In the numerical results from Figs. 9 and 10, the tunnel crown showed tensile failure and developed a couple of structural hinges. The numerical results were validated by the experimental results, as shown in the left image in Fig. 9, where the failure in tension was due to the development of five structural hinges, points A to E. 
Fig. 7 Failure state of UDEC B under uniform load $(H=1075 \mathrm{~mm})$
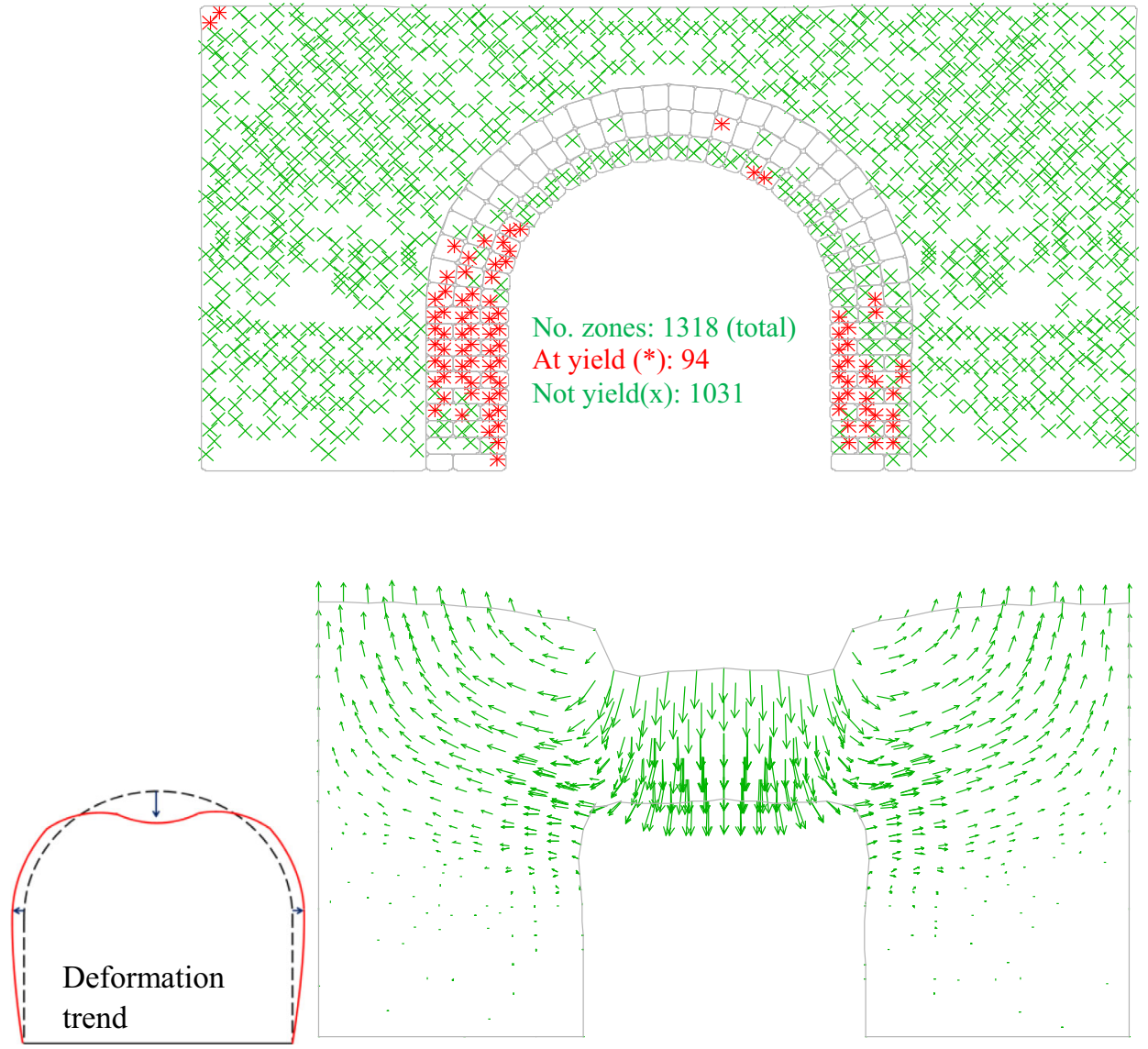

Fig. 8 Displacement vectors for UDEC C under concentrated load $(H=1170 \mathrm{~mm})$

\subsection{Prospective Impacts}

Decisions on whether to conduct further CE approaches for resource optimisation and recovery of underground structures are highly dependent on the environmental benefit and resource efficiency (economic benefit) compared with the use of virgin materials. Numerical prediction served as a means to link CE approaches to the practical field of underground infrastructures and upcycle resource management and waste treatment. Since the numerical modelling has been verified by experimental models, it is reliable and can predict the structural performance of the underground infrastructures during the service life and guide the design of infrastructures to implement proper CE approaches.

The prospective advantages of $\mathrm{CE}$ approaches using numerical prediction are strongly linked to (a) greenhouse gas (GHG) emissions and global warming potential (GWP) and (b) energy demand and embodied energy to quantify the environmental impacts on climate change; and (c) resource demand to quantify the economic impacts with much less demand for virgin resources. To demonstrate the prospective impacts of $\mathrm{CE}$ approaches using numerical prediction, a case study has been analysed using the tunnel model UDEC A (a brick-lined tunnel under uniform load, at soil depth $H=1075 \mathrm{~mm}$ ). After numerical modelling of the model UDEC A, the failure profile of the model (see Fig. 6) indicated 42 damaged bricks with recycling opportunity (equivalent to 0.10 tonnes $/ \mathrm{m}$ in the length of the tunnel). It also indicated 72 non-damaged bricks with high potential for reuse (equivalent to 0.17 tonnes $/ \mathrm{m}$ in the length of the tunnel).

The corresponding CE approaches including reuse and recycling have been employed to calculate the environmental and resource impacts of the measures. Compared with a linear economy approach (take-make-use-dispose), $\mathrm{CE}$ approaches show great advantages, especially when reusing non-yielded brick components, as shown in Table 6. Research [61-63] has shown that the embodied energy of a new brick is $6.9 \mathrm{MJ}$, which is equivalent to $0.29 \mathrm{~kg}$ of $\mathrm{CO}_{2} / \mathrm{kWh}$ of electricity. Given one brick is equivalent to $1.92 \mathrm{kWh}$ of electricity, the GHG emissions per brick are $0.56 \mathrm{~kg} \mathrm{CO}_{2}$. The embodied carbon savings of reclaiming 1 tonne of bricks is up to 0.9 tonnes compared with recycling and landfilling [26]. Therefore, according to the numerical prediction results for circular economy approaches (reuse and recycling potential of bricks), the GHG emissions and energy demand/embodied energy for 

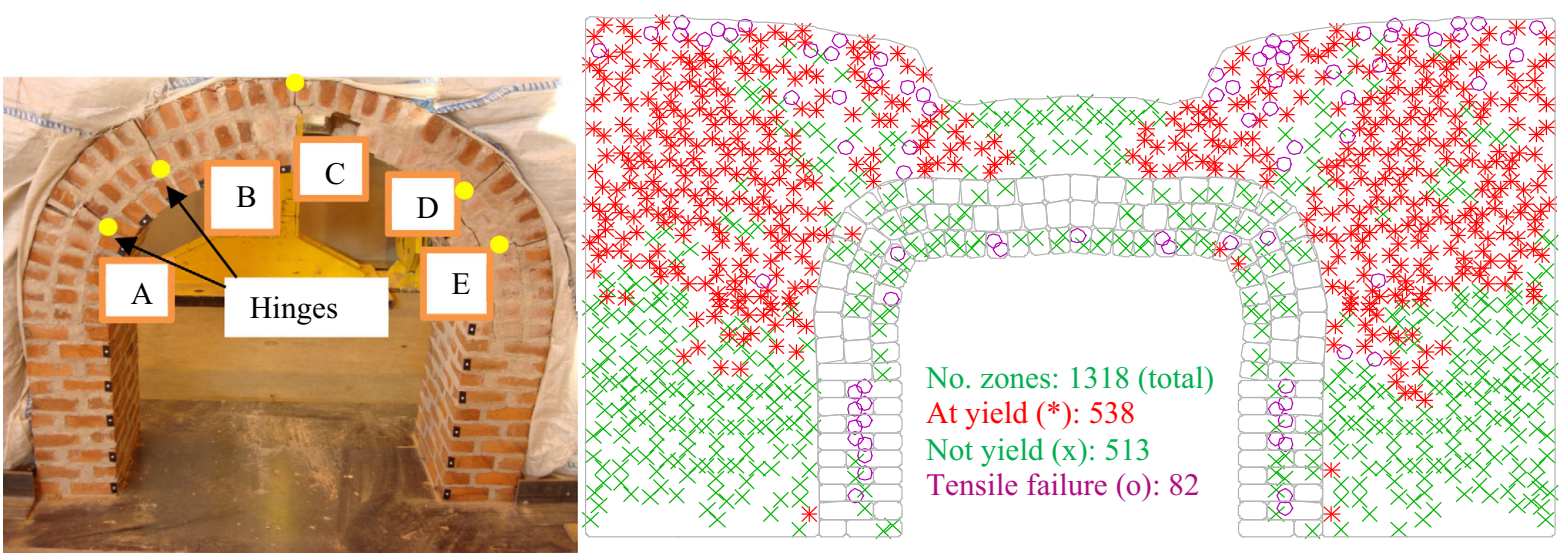

Fig. 9 Plastic state of UDEC C compared with experimental test 3 under concentrated load $(H=1170 \mathrm{~mm})$

Fig. 10 Failure pattern of UDEC C under concentrated load indicating hinges $(H=1170 \mathrm{~mm})$

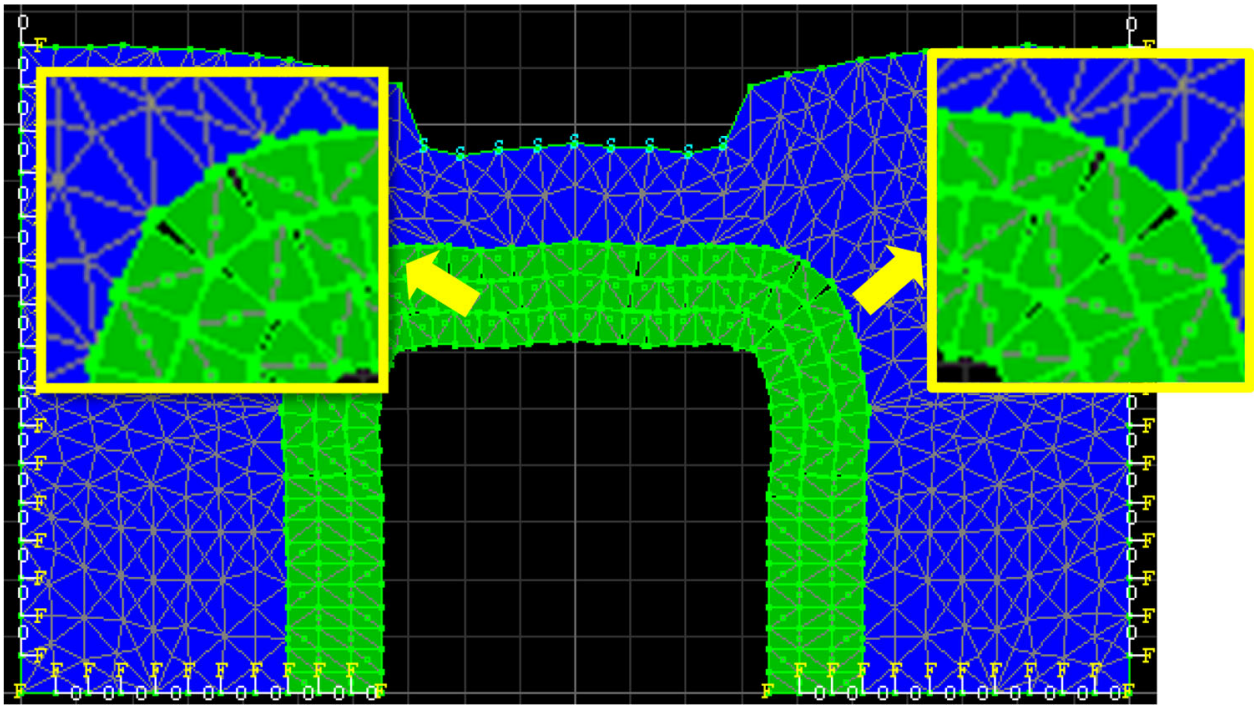

the reuse and recycling approaches amount to $10 \%$ and $90 \%$ of the linear economy approach, respectively.

Table 6 indicates that, as expected, the carbon emissions of bricks for reuse (non-yielded bricks in simulation) are only a very small fraction (9.6\%) of that for manufacturing new bricks, while bricks for recycling (yielded and failed ones in simulation) have slightly lower carbon emissions than for manufacturing ( $90 \%$ of the manufacturing). The results show a large reduction of the energy demand using reclaimed bricks over new bricks (dropped by 90\%). Similarly, by reusing brick components and recycling damaged bricks, the resource demand for virgin materials (clay) and new products (bricks) is reduced by 0.43 tonnes/ $\mathrm{m}$ and 0.36 tonnes $/ \mathrm{m}$ over the length of the tunnel, respectively. Thus, the original waste will be reduced and upgraded to a precious resource during the process, in order to establish a new business model within a closed loop in the future and a more sustainable supply chain towards a circular economy. Based on the above discussion and evidence shown in Table 6, for any specific underground structure, it is also strongly suggested that numerical simulation be used to predict whether the approach provides environmental benefits.

\section{Conclusions and Future Research}

Potential circular economy approaches and solutions have been introduced to tackle the key challenges and increase the resource efficiency of construction materials for the design and maintenance of underground infrastructures.

Numerical models of small-scale brick-lined railway tunnels have been developed, and quantitative agreement was achieved with the results of the experimental tests. Therefore, it is possible to predict weaker areas (reaching the material yield and failure strength) and even local failure mechanisms of segmental structures. The numerical modelling and subsequent prediction stand out as a 
Table 6 Linear versus corresponding circular economy approaches: comparison of environmental and resource indicators for underground infrastructures

\begin{tabular}{|c|c|c|c|}
\hline \multirow[t]{2}{*}{ Impacts } & \multirow{2}{*}{$\begin{array}{l}\text { Linear economy approach } \\
\text { Manufacture of new } \\
\text { bricks-disposal }\end{array}$} & \multicolumn{2}{|c|}{ Corresponding CE approaches after numerical prediction } \\
\hline & & $\begin{array}{l}\text { Brick components (non- } \\
\text { yielded) for reuse }\end{array}$ & $\begin{array}{l}\text { Materials (yielded, failed and damaged } \\
\text { bricks) for recycling }\end{array}$ \\
\hline $\begin{array}{l}\text { Greenhouse gas (GHG) emissions } \\
\quad\left(\mathrm{kg} \mathrm{CO}_{2} / \text { brick }^{\mathrm{a}}\right)\end{array}$ & $0.560^{\mathrm{c}}$ & $0.054^{\mathrm{d}}$ & $0.504^{\mathrm{d}}$ \\
\hline $\begin{array}{l}\text { Energy demand/embodied energy } \\
\left(\mathrm{MJ} / \text { brick }^{\mathrm{a}}\right)\end{array}$ & $6.90^{\mathrm{b}}$ & 0.67 & 6.26 \\
\hline $\begin{array}{l}\text { Resource demand (tonnes/m tunnel } \\
\text { length) }\end{array}$ & 0.26 & -0.17 & -0.10 \\
\hline \multicolumn{4}{|l|}{ ane brick is assumed to be $2.3 \mathrm{~kg}$} \\
\hline \multicolumn{4}{|c|}{${ }^{b}$ Embodied energy (EE) of a new brick [61-63] } \\
\hline \multicolumn{4}{|c|}{${ }^{\mathrm{C}}$ Carbon emissions of a new brick [61-63] } \\
\hline
\end{tabular}

practical circular economy approach. They serve as a powerful tool for carrying out easy repair and waste material optimisation in underground infrastructures for a circular economy. Furthermore, the entire concept would be of greater benefit for predicting the mechanical behaviour of the popular segmental concrete lining as one type of jointless masonry structure. By varying the material and interface properties, numerical models can be adapted to agree with real scenarios.

As a recommendation for further modelling work, it would be interesting to introduce other constitutive models related to masonry and concrete linings to simulate longerterm deformation and the likelihood of major cracking of segmental linings after years of degradation. More realistic conditions could be applied, such as under cyclic loading, representing moving vehicles on the rail, or under extreme conditions such as earthquakes. A railway field case study using the developed model can serve as a powerful performance-based tool to identify the appropriate CE approaches. This would be very beneficial for analysing the reuse/recycling potential for metro tunnels towards a circular economy, and for carrying out easy repair and design for adaptability, disassembly and recoverability of underground infrastructures for a circular economy.

Acknowledgements The experimental work was conducted while Dr Han-Mei Chen was studying at the University of Nottingham towards a Ph.D. degree, supervised by Professor Hai-Sui Yu and Dr Martin Smith. The authors are grateful to the supervisors for research guidance and all technicians working in the Nottingham Centre for Geomechanics and the laboratory of Civil Engineering for their assistance throughout the experimental work.

Open Access This article is distributed under the terms of the Creative Commons Attribution 4.0 International License (http://crea tivecommons.org/licenses/by/4.0/), which permits unrestricted use, distribution, and reproduction in any medium, provided you give appropriate credit to the original author(s) and the source, provide a link to the Creative Commons license, and indicate if changes were made.

\section{Compliance with Ethical Standards}

Conflict of interest The authors declare that they have no conflict of interest with regard to the manuscript.

\section{References}

1. EMF (Ellen MacArthur Foundation) (2015a) Growth within: a circular economy vision for a competitive Europe. http://www. ellenmacarthurfoundation.org/assets/downloads/publications/ EllenMacArthurFoundation_Growth-Within_July15.pdf. Accessed 07 June 2019

2. EC (European Council) (2008) Directive 2008/98/EC of the European Parliament and of the Council of 19 November 2008 on waste and repealing certain Directives. Official Journal of the European Union L312/3

3. HM Government (2008) Strategy for Sustainable Construction. HM Government in association with the Strategic Forum. http:// www.berr.gov.uk/files/file46535.pdf. Accessed 10 April 2014

4. Construction Resources and Waste Platform (2010) Construction resources and waste roadmap: 2010 update. BRE, Watford

5. Defra (2011) Statistical data set ENV23-UK waste data and management-total UK waste generation by sector 2004 to 2008 . Defra, London

6. Smith A (2013a) Clay bricks and clay blocks: a resource efficiency action plan. London, UK, The green construction board. http://www.wrap.org.uk/sites/files/wrap/CBCB\%20REAP\% 20October\%202013.pdf. Accessed 05 June 2019

7. Smith A (2013b) Precast concrete: a resource efficiency action plan. London, UK, The green construction board. http://www. wrap.org.uk/sites/files/wrap/Precast\%20REAP\%20October\% 202013_0.pdf. Accessed 05 June 2019

8. REAPs (2017) REAPs (Resource Efficiency Action Plans): Bricks, blocks and concrete-1st progress report. https://www. 
brick.org.uk/admin/resources/reap-progress-report-1.pdf. Accessed 05 June 2019

9. UKGBC (2019) Circular economy guidance for construction clients: How to practically apply circular economy principles at the project brief stage, UKGBC

10. BDA (Brick Development Association) (2014a) BDA comment on the use of reclaimed clay bricks. BDA, London, UK, pp 10-11. http://www.brick.org.uk/admin/resources/g-reclaimedbrickwork.pdf. Accessed 05 June 2019

11. Hradil P, Talja A, Wahlström M, Huuhka S, Lahdensivu J, Pikkuvirta J (2014) Re-use of structural elements-Environmentally efficient recovery of building components

12. Economy C (2019) The circularity gap report-closing the circularity gap in a $9 \%$ world. Circle Economy, Amsterdam

13. URBACT (2013) Cities of tomorrow-action today. URBACT II capitalisation. Building energy efficiency in European Cities. URBACT, France

14. United Nations (2015a) Paris Agreement. https://unfccc.int/sites/ default/files/english_paris_agreement.pdf. Accessed 26 Mar 2019

15. United Nations (2015b) Transforming the World: the 2030 Agenda for Sustainable Development. A/RES/70/1

16. EMF (Ellen MacArthur Foundation) (2015b) Delivering the circular economy: a tool kit for policy makers. Construction and Real Estate

17. European Commission (2015) Roadmap: circular economy strategy. http://ec.europa.eu/smartregulation/impact/planned_ia/ docs/2015_env,_065_env + _032_circular_economy_en.pdf. Accessed 26 Oct 2015

18. Mendoza JMF, Sharmina M, Gallego-Schmid A, Heyes G, Azapagic A (2017) Integrating backcasting and eco-design for the circular economy: the BECE framework. J Ind Ecol 21(3):526-544

19. Hopkinson P, Chen HM, Zhou K, Wang Y, Lam D (2019) Recovery and reuse of structural products from end-of-life buildings. Proc Inst Civil Eng Eng Sustain 172(3):119-128. https://doi.org/10.1680/jensu.18.00007

20. European Commission (2019) JRC technical report: standardisation needs for the design of underground structures

21. BBC (2016) Climate change: the massive $\mathrm{CO}_{2}$ emitter you may not know about, https://www.bbc.co.uk/news/science-environ ment-46455844. Accessed 10 May 2019

22. Heyes G, Sharmina M, Mendoza JMF, Gallego-Schmid A, Azapagic A (2018) Developing and implementing circular economy business models in service-oriented technology companies. J Clean Prod 177:621-632

23. Defra NS (2019) Monthly statistics of building materials and components. Department for Environment, Food and Rural Affairs and National Statistics, London, p 47

24. BDA (Brick Development Association) (2014b) Scottish traditional brickwork. http://www.brick.org.uk/admin/resources/gscottish-traditional-brickwork.pdf. Accessed 18 Dec 2018

25. Klang A, Vikman P, BrattebØ RattebØ H (2003) Sustainable management of demolition waste-an integrated model for the evaluation of environmental, economic and social aspects. In: Resources, conservation and recycling, vol 38, no 4, pp 317-334

26. BioRegional Development Group, Reclamation Led Approach to Demolition (2007) https://www.bioregional.com/wp-content/ uploads/2015/05/ReclamationtoDemolition_Jul07.pdf. Accessed 03 Dec 2018

27. Huuhka S, Kaasalainen T, Hakanen JH, Lahdensivu J (2015) Reusing concrete panels from buildings for building: potential in Finnish 1970s mass housing. Resour Conserv Recycl 101:105-121. https://doi.org/10.1016/j.resconrec.2015.05.017

28. Pomponi F, Moncaster A (2016) Embodied carbon mitigation reduction in the built environment-what does the evidence say? J Environ Manage 181:687-700
29. Eberhardt LCM, Birgisdóttir H, Birkved M (2019) Life cycle assessment of a Danish office building designed for disassembly. Build Res Inf 47(6):666-680

30. Densley D, Tingley D, Davison B (2011) Design for deconstruction and material reuse. Proc ICE Energy 164:195-204

31. Huuhka S (2010a) Kierrätys arkkitehtuurissa: Betonielementtien ja muiden rakennusosien uudelleenkäyttö uudisrakentamisessa ja lähiöiden energiatehokkaassa korjaus- ja täydennysrakentamisessa. MSc thesis, Tampere University of Technology, Tampere, Finland. http://URN.fi/URN:NBN:fi:tty201004161101. Accessed 19 July 2018. (in Finnish)

32. Huuhka S (2010) Purkubetoni kierrätetään tienpohjiksi-tulevaisuudessa ehkä myös taloiksi. Betoni 2010(2):50-55 (in Finnish)

33. Sansom M, Avery N (2014) Briefing: reuse and recycling rates of UK steel demolition arisings. Proc Inst Civil Eng Eng Sustain 167(3):89-94

34. Broadbent C (2016) Steel's recyclability: demonstrating the benefits of recycling steel to achieve a circular economy. Int $\mathbf{J}$ Life Cycle Assess 21(11):1658-1665. https://doi.org/10.1007/ s11367-016-1081-1

35. Wang P, Li W, Kara S (2017) Cradle-to-cradle modeling of the future steel flow in China. Resour Conserv Recycl 117:45-57. https://doi.org/10.1016/j.resconrec.2015.07.009

36. Diener DL, Tillman AM (2015) Component end-of-life management: exploring opportunities and related benefits of remanufacturing and functional recycling. Resour Conserv Recycl 102:80-93. https://doi.org/10.1016/j.resconrec.2015.06.006

37. Dunant CF, Drewniok MP, Sansom M et al (2017) Real and perceived barriers to steel re-use across the UK construction value chain. Resour Conserv Recycl 126:118-131. https://doi. org/10.1016/j.resconrec.2017.07.036

38. Rebrick (2013) http://ec.europa.eu/environment/eco-innovation/ projects/en/projects/rebrick. Accessed 10 July 2019

39. Sencu RM, Wang YC, Yang J, Lam D (2019) Performance evaluation of demountable shear connectors with collar step at ambient and elevated temperatures. Eng Struct 194:94-105. https://doi.org/10.1016/j.engstruct.2019.05.059

40. Dai X, Lam D, Sheehan T, Yang J, Zhou K (2018) Use of bolted shear connectors in composite construction. In: Proceedings of the 12th international conference on advances in steel-concrete composite structures. ASCCS 2018. Editorial Universitat Politècnica de València, pp 475-482

41. UIA (Urban Innovation Actions) (2018) Identify and Test Innovative Solutions for Sustainable Urban Development. UIA, Lille, France. http://www.uia-initiative.eu/en/uia-cities/kerkrade. Accessed 23 June 2019

42. DRAGON (2015) A tunnel yields a whole lot of valuable materials. http://www.dragonproject.eu. Accessed 07 June 2019

43. Zhou R, Chen HM (2019) Mesoscopic investigation of size effect in notched concrete beams: the role of fracture process zone. Eng Fract Mech 212:136-152

44. Zhou R, Lu Y (2018) A mesoscale interface approach to modelling fractures in concrete for material investigation. Constr Build Mater 165:608-620

45. Betti M, Drosopoulos GA, Stavroulakis GE (2008) Two nonlinear finite element models developed for the assessment of failure of masonry arches. Comptes Rendus Mécanique 336(1-2):42-53

46. Lourenço PB (1998) Experimental and numerical issues in the modelling of the mechanical behaviour of masonry. In: Roca P, González JL, Oñate E, Lourenço PB (eds) Structural analysis of historical constructions II. Possibilities of numerical and experimental techniques, CIMNE, Barcelona, pp 57-92 
47. Valluzzi MR, Binda L, Modena C (2005) Mechanical behaviour of historic masonry structures strengthened by bed joints structural repointing. Constr Build Mater 19:63-73

48. Idris J, Verdel T, Al-Heib M (2008) Numerical modelling and mechanical behaviour analysis of ancient tunnel masonry structures. Tunn Undergr Space Technol 23:251-263

49. Chen H-M, Yu H-S, Smith MJ (2016) Physical model tests and numerical simulation for assessing the stability of brick-lined tunnels. Tunnel Undergr Space Technol 53(2016):109-119

50. The world's largest tunnel database (2004) The world's longest Tunnel page database, 2004: http://home.no.net/lotsberg/. Accessed 27 May 2019

51. Murphy E (2016) Reconstruction of Farnworth Tunnels, The British Tunnelling Society

52. Asokan P, Osmani M, Price ADF (2009) Assessing the recycling potential of glass fibre reinforced plastic waste in concrete and cement composites. J Clean Prod 17(9):821-829

53. Jin Y, Ding W, Yan Z, Soga K, Li Z (2017) Experimental investigation of the nonlinear behavior of segmental joints in a water-conveyance tunnel. Tunn Undergr Space Technol 68:153-166

54. Goodfellow RJF (2011) Concrete for underground structuresguidelines for design and construction. Society for Mining, Metallurgy, and Exploration (SME). https://app.knovel.com/ hotlink/toc/id:kpCUSGDC01/concrete-underground/concreteunderground. Accessed 05 Oct 2018

55. WSP and MMM Group (2017) George Massey tunnel replacement project tunnel decommissioning options. https://engage.gov. bc.ca/app/uploads/sites/52/2017/02/GMT-Tunnel-Decommision ing-Options-Feb-2017.pdf. Accessed 05 Apr 2019

56. D'Aloia Schwartzentruber L, Humbert E, Bonnet R (2015) Life Cycle Assessment applied to the construction of tunnel. In: SEE
Tunnel: promoting tunneling in SEE Region"ITA WTC 2015 congress and 41st general assembly. Lacroma Valamar Congress Center, Dubrovnik, Croatia

57. Chen H-M (2014) Physical model tests and numerical simulation for assessing the stability of tunnels. Ph.D. Thesis, Faculty of Engineering, University of Nottingham, UK

58. Chen H-M, Smith MJ, Yu H-S, Kokkas N (2014) Monitoring the deformation of small scale model tunnels under load testing. Surv Rev 46(339):417-425

59. Chen H-M, Yu H-S, Smith MJ, Kokkas N (2013) Advanced monitoring techniques for assessing the stability of small-scale tunnels. In: 2nd Joint international symposium on deformation monitoring (JISDM), The University of Nottingham on 9-11 September 2013

60. Juspi S (2007) Experimental validation of the shakedown concept for pavement analysis and design. Ph.D. Thesis, Department of Civil Engineering, University of Nottingham

61. Hammond GP, Jones C (2011) Inventory of carbon and energy version 2.0 (ICE V2. 0). Department of Mechanical Engineering, University of Bath, Bath, UK

62. BDA (2016) Brick sustainability report. https://www.brick.org. uk/admin/resources/brick-sustainability-report-2016-1.pdf. Accessed 14 Dec 2018

63. BDA (2017) REAP Report, the sustainability section. https:// www.brick.org.uk/admin/resources/reap-progress-report-1.pdf. Accessed 17 Dec 2018

64. Kay T, Essex J (2008) Pushing reuse: towards a low-carbon construction industry. Salvo Llp, London, UK, BioRegional, Wallington, UK. https://bioregional.com.au/wp-content/uploads/ 2015/05/PushingReuse.pdf. Accessed 20 Nov 2018 